\title{
ADRIAN SZUMSKI
}

\section{Interpol wobec problemu tzw. zagranicznych bojowników terrorystycznych (foreign terrorist fighters)}

Współczesny terroryzm jest zjawiskiem o zróżnicowanych obliczach i źródłach. Może wiązać się zarówno z działalnością podmiotów wewnątrzpaństwowych, jak i z aktywnością obywateli pochodzących z innych państw. W ostatnich latach jednym $\mathrm{z}$ ważniejszych zagadnień związanych z zapobieganiem i zwalczaniem zagrożeń terrorystycznych stał się problem tzw. zagranicznych bojowników terrorystycznych (foreign terrorist fighters - FTF).

Zgodnie z Rezolucją Rady Bezpieczeństwa ONZ 2178 z 24 września 2014 roku pod pojęciem zagranicznych bojowników terrorystycznych rozumie się ,jednostki, które przemieszczają się do kraju innego niż kraj ich miejsca zamieszkania lub narodowości, w celu popełnienia, planowania lub przygotowania ataków terrorystycznych bądź też oferowania swoich usług w zakresie szkolenia terrorystycznego albo uczestnictwa samemu w takim szkoleniu, w tym również w powiązaniu z konfliktem zbrojnym" ". Osoby takie rekrutowane są przez organizacje terrorystyczne spośród obywateli różnych państw (w tym europejskich). Problem zagranicznych bojowników jest poważny z kilku powodów. Po pierwsze, stanowią oni zasób ludzki, który może być wykorzystany podczas bezpośrednich akcji na obszarach objętych konfliktami zbrojnymi. Mogą oni zatem stać się czynnikiem podtrzymującym czy nawet eskalującym istniejące konflikty. Drugim (i być może nawet poważniejszym z punktu widzenia bezpieczeństwa europejskiego) problemem jest rola takich jednostek w kreowaniu i realizacji strategii informacyjnej organizacji terrorystycznych. $Z$ uwagi na to, że są to zazwyczaj osoby, które urodziły się i wychowywały w krajach Zachodu, mają one zwykle dobre rozeznanie w kwestiach demografii, wrażliwości oraz podatności na przekaz

${ }^{1}$ U.N. Security Council Resolution 5/Res/2178 (2014), s. 2. 
organizacji terrorystycznych wśród społeczeństw państw, z których pochodzą ${ }^{2}$. Dzięki temu mogą one ukierunkowywać strategię informacyjną organizacji terrorystycznych $\mathrm{w}$ tych państwach tak, aby była ona bardziej skuteczna, co jest niezwykle groźne np. w kontekście pozyskiwania nowych zwolenników tych organizacji. Wreszcie, po trzecie, istnieje ryzyko powrotu osób zaliczanych do kategorii zagranicznych bojowników terrorystycznych do krajów ich pochodzenia i prowadzenia tam działalności terrorystycznej. Dotyczy to zarówno członków organizacji terrorystycznych, jak i pojedynczych weteranów konfliktów, którzy — z racji swojego przygotowania i wyszkolenia — mogą być w stanie samodzielnie przygotowywać ataki terrorystyczne ${ }^{3}$.

Problem zagranicznych bojowników terrorystycznych jest obecnie obiektem zainteresowania zarówno państw, jak i organizacji międzynarodowych, do których zalicza się także Międzynarodowa Organizacja Policji Kryminalnej (Interpol).

Działania podejmowane przez Interpol w zwalczaniu opisywanego problemu wiążą się ściśle z charakterem tej organizacji, będącym z kolei konsekwencją postanowień dokumentu konstytuującego Interpol, czyli Statutu z dnia 13 czerwca 1956 roku. Zgodnie bowiem z art. 2 tego dokumentu organizacja ta ma na celu:

— zapewnianie i rozwijanie jak najszerszej wzajemnej pomocy wszystkich służb policji kryminalnej w granicach praw obowiązujących w poszczególnych państwach i w duchu Powszechnej Deklaracji Praw Człowieka;

— ustanawianie i rozwijanie wszelkich form działania mogących służyć skutecznemu zapobieganiu i ściganiu przestępczości pospolitej.

Jednocześnie, zgodnie z art. 3 Statutu, podejmowanie przez Organizację jakiejkolwiek działalności lub interwencji o charakterze politycznym, wojskowym, religijnym lub rasowym jest ściśle zabronione ${ }^{4}$.

Oprócz Statutu ważną podstawę działań Interpolu w walce z problemem zagranicznych bojowników terrorystycznych stanowi cytowana już wcześniej Rezolucja Rady Bezpieczeństwa ONZ, która uznała istotną rolę Interpolu w tym zakresie.

Biorąc pod uwagę zarówno postanowienia Statutu Interpolu, jak i zapisy Rezolucji, można wskazać kilka najważniejszych środków, z których organizacja ta i jej członkowie mogą korzystać $\mathrm{w}$ walce $\mathrm{z}$ omawianym zjawiskiem. Pierwszym z nich jest system globalnej łączności Interpolu I-24/7, który w tym kontekście

${ }^{2}$ R. Zgryziewicz, Strategia komunikacyjna Daesh zagrożeniem dla współczesnej Europy, „e-Politikon” 2016, nr XX, s. 106.

${ }^{3}$ K. Rękawek, Zagraniczni bojownicy w Syrii i Iraku: skala problemu i zagrożenie dla Europy, „Biuletyn PISM” 2014, nr 110, s. 2.

${ }^{4}$ W kontekście analizowanego zagadnienia warto na marginesie zwrócić uwagę, że przepis ten stanowił swego czasu istotny problem, jeśli chodzi o możliwości działania Interpolu w zakresie zwalczania terroryzmu; zob. H. Kołecki, Działalność Interpolu w zakresie zwalczania terroryzmu międzynarodowego, [w:] Terroryzm. Aspekty prawno-międzynarodowe, kryminalistyczne i policyjne, red. K. Sławik, Materiały Sympozjum zorganizowanego przez Wydział Prawa Uniwersytetu Szczecińskiego, Szczecin, 29-30.11.1991, Poznań 1993, s. 115 i 116. 
pozwala przede wszystkim na wymianę informacji operacyjnych pomiędzy krajami członkowskimi oraz Sekretariatem Generalnym Interpolu na temat zagranicznych bojowników terrorystycznych. Zaletą systemu I-24/7 pod tym względem jest szybkość działania oraz całodobowa dostępność, co pozwala na wymianę informacji w czasie rzeczywistym, bez konieczności długotrwałego oczekiwania na odpowiedź ${ }^{5}$.

System łączności I-24/7 umożliwia ponadto dostęp do baz danych i specjalistycznych rejestrów administrowanych przez Sekretariat Generalny Interpolu. Spośród nich wydaje się, że kluczowe znaczenie z punktu widzenia zwalczania problemu zagranicznych bojowników terrorystycznych mają następujące bazy danych:

- Nominal - baza osobowa zawierająca informacje: o osobach poszukiwanych w celu ekstradycji, osobach zaginionych, do ustalenia miejsca pobytu i o niezidentyfikowanych zwłokach. Dane identyfikacyjne zawarte w tej bazie obejmują odbitki linii papilarnych, informacje o DNA i zdjęcia. Przeszukania w niej mogą być realizowane także po aliasach i z zastosowaniem kryterium fonetycznego pozwalającego na wychwycenie błędów w transkrypcji6;

- SLTD (Stolen and Lost Travel Documents) - baza skradzionych i zgubionych dokumentów podróżnych, umożliwiająca Krajowym Biurom Interpolu i innym upoważnionym podmiotom (np. służbom imigracyjnym i odpowiedzialnym za kontrolę granic) natychmiastową ocenę autentyczności i ważności takich dokumentów, jak paszporty, dowody osobiste czy wizy ${ }^{7}$. Możliwości stwarzane przez tę bazę są niezwykle istotne, ponieważ z omawianym problemem ściśle wiąże się kwestia fałszerstw dokumentów tożsamości, których dopuszczają się organizacje terrorystyczne, aby ułatwić działalność swoim bojownikom. Przykładem może tutaj być Państwo Islamskie, które dzięki przejęciu urządzeń poligraficznych w opanowanych przez siebie miastach Syrii i Iraku (oraz dzięki temu, że najprawdopodobniej ma dostęp także do danych biometrycznych obywateli Syrii) jest w stanie wytwarzać fałszywe dokumenty tych krajów, nieróżniące się od oryginałów. Ponadto organizacja ta skierowała instrukcje do potencjalnych zagranicznych bojowników, zachęcając ich do przyjazdu na Bliski Wschód z oryginalnymi dokumentami tożsamości, a następnie do powrotu $\mathrm{z}$ dokumentami fałszywymi lub należącymi do innych osób ${ }^{8}$;

— baza prowadzona przez zespół zadaniowy FTF (Fusion Task Force) — zawiera informacje o osobach podejrzanych o finansowanie, wspieranie ugrupowań

5 https://www.interpol.int/INTERPOL-expertise/Data-exchange/I-24-7 (dostęp: 5.03.2017).

${ }^{6}$ B. Kołdys, BMWP KGP - Krajowe Biuro Interpolu, „Kwartalnik Policyjny” 2014, nr 4, s. 18 .

7 https://www.interpol.int/INTERPOL-expertise/Border-management/SLTD-Database (dostęp: 5.03.2017).

8 K. Izak, Imigranci a prawo, dokumenty i bezpieczeństwo narodowe, „Człowiek i Dokumenty” 2016, styczeń-marzec, s. 20. 
terrorystycznych lub powiązania z nimi ${ }^{9}$. Umożliwia ona w szczególności identyfikację grup terrorystycznych i ich członków, ustalenie charakteru działalności przestępczej danej organizacji, jej składu osobowego, struktury hierarchicznej, obszarów działania i modus operandi ${ }^{10}$.

Ważnym uzupełnieniem prezentowanych zasobów (zwłaszcza bazy SLTD) jest rejestr TDAWN (Travel Documents Associated with Notices) stanowiący zbiór informacji o dokumentach podróżnych powiązanych z osobami, za którymi zostały wysłane noty Interpolu ${ }^{11}$.

Innym instrumentem wspomagającym korzystanie z bazy SLTD jest aplikacja o nazwie I-Checkit umożliwiająca przedsiębiorstwom transportowym, turystycznym i instytucjom bankowym sprawne przekazywanie do Interpolu informacji o paszportach ich klientów; dane te mogą być następnie zweryfikowane w oparciu o bazę SLTD (należy jednak zaznaczyć, że ze względów bezpieczeństwa podmioty prywatne nie mają bezpośredniego dostępu do tej bazy). Dzięki temu I-Checkit może zarówno służyć wykryciu skradzionych bądź bezprawnie wykorzystywanych dokumentów podróżnych, jak również doprowadzić do zatrzymania osób, które się nimi posługują ${ }^{12}$.

Odnosząc się do znaczenia wymienionych baz danych i rejestrów, należy stwierdzić, że korzystanie z nich przede wszystkim ułatwia skuteczną kontrolę granic, co stanowi z kolei pierwszy krok w zapobieganiu przemieszczania się zagranicznych bojowników terrorystycznych. Pełnią one zatem funkcję ważnego instrumentu o charakterze prewencyjnym. Ponadto dane w nich zawarte umożliwiają wykrywanie przestępstw powiązanych z działalnością terrorystyczną.

Kolejnym ważnym elementem wykorzystywanym we współpracy w ramach Interpolu przy zwalczaniu problemu zagranicznych bojowników terrorystycznych jest system not i dyfuzji, z którego korzystanie również umożliwia system łączności I-24/7. Noty zawierają prośby o współpracę lub ostrzeżenia umożliwiające policjom państw członkowskich Interpolu dzielenie się najważniejszymi informacjami kryminalnymi. Publikowane są przez Sekretariat Generalny tej organizacji na prośbę Krajowych Biur Interpolu oraz upoważnionych podmiotów ${ }^{13}$. Z kolei dyfuzja to zawiadomienie o wszczęciu poszukiwań osób podejrzanych w skali międzynarodowej przez krajowe organy wymiaru sprawiedliwości. Dyfuzje są sporządzane i rozsyłane przez krajowe jednostki za pośrednictwem systemu I-24/7 bezpośrednio do ich odpowiedników w państwach członkowskich

${ }^{9}$ B. Kołdys, op. cit., s. 18.

$10 \mathrm{http}: / /$ www.interpol.int/Public/FusionTaskForce/objectives.asp (dostęp: 1.11.2010).

11 https://www.interpol.int/content/download/29749/390579/version/3/file/Information\%20 Sheet-Foreign\%20Fighter.pdf (dostęp: 5.03.2017).

12 INTERPOL I-Checkit: Proactive Policing in the New Age of Crime and Technology, „The Police Chief" 2014, nr 81 (August 2014): online only, http://www.policechiefmagazine.org/interpoli-checkit-proactive-policing/ (dostęp: 26.08.2016).

$13 \mathrm{https}$ ://www.interpol.int/INTERPOL-expertise/Notices (dostęp: 10.03.2017). 
Interpolu, przy czym mogą być one przekazywane do wszystkich lub tylko do wybranych Krajowych Biur Interpolu ${ }^{14}$. W kontekście zwalczania zagrożeń związanych z zagranicznymi bojownikami terrorystycznymi istotna jest zwłaszcza Nota Czerwona (będąca informacją, że dana osoba poszukiwana jest przez wymiar sprawiedliwości jednego z państw członkowskich Interpolu albo przez międzynarodowy sąd lub trybunał karny ${ }^{15}$ ), Niebieska (wydawana w celu uzyskania dodatkowych informacji o tożsamości danej osoby, miejscu pobytu lub aktywności w powiązaniu z przestępstwem), Zielona (stanowiąca ostrzeżenie i informację o osobie, która dopuściła się przestępstwa kryminalnego) oraz Żółta (ułatwiająca lokalizację zaginionej osoby $)^{16}$. Dodatkowo Interpol wspólnie z Radą Bezpieczeństwa ONZ wydają tzw. Notę Specjalną, która dotyczy jednostek lub innych podmiotów będących obiektem sankcji ze strony Rady Bezpieczeństwa (m.in. ze względu na prowadzoną przez nie działalność terrorystyczną) ${ }^{17}$. System not i dyfuzji umożliwia szybkie powiadomienie danego kraju np. o prawdopodobnym pobycie na jego terytorium osoby zaliczanej do kategorii zagranicznych bojowników terrorystycznych, a tym samym reakcję odpowiednich organów ścigania.

Wreszcie, istotnym instrumentem wykorzystywanym w praktyce Interpolu są specjalne projekty ukierunkowane na zwalczanie zagrożeń terrorystycznych. Pod tym względem szczególna rola przypada zorganizowanemu przez tę organizację centrum CTF (Counter-Terrorism Fusion Centre). Jego zadaniem jest przede wszystkim badanie hierarchii organizacji terrorystycznych, prowadzonej przez nie działalności szkoleniowej, sposobów ich finansowania oraz metod i motywów postępowania. Działalność CTF ma charakter globalny i opiera się na realizacji wielu projektów zorientowanych na współpracę regionalną, ale jednocześnie powiązanych z sobą. Tego typu projektami realizowanymi obecnie są ${ }^{18}$ :

— projekt Al Qabdah (dla państw Bliskiego Wschodu i Afryki Północnej);

— projekt Amazon (dla krajów amerykańskich);

- projekt Baobab (Afryka);

— projekt Kalkan (Azja Środkowa);

— projekt Nexus (Europa);

— projekt Pacific (Azja Południowo-Wschodnia i wyspy Pacyfiku).

Podstawowym celem tych projektów jest transgraniczna wymiana informacji oraz poprawa skuteczności działań służb ochrony porządku i bezpieczeństwa publicznego poprzez promowanie i implementację nowych metod służących walce

14 T. Safjański, Prawne aspekty wykorzystania wsparcia Interpolu w poszukiwaniu osób podejrzanych w świetle art.605a k.p.k., „Prokuratura i Prawo” 2016, nr 10, s. 162.

15 Ibidem, s. 157.

$16 \mathrm{https} / /$ www.interpol.int/content/download/29749/390579/version/3/file/Information\%20 Sheet-Foreign\%20Fighter.pdf (dostęp: 5.03.2017).

$17 \mathrm{https} / / /$ www.interpol.int/INTERPOL-expertise/Notices/Special-Notices (dostęp: 12.03.2017).

$18 \mathrm{https} / / /$ www.interpol.int/Crime-areas/Terrorism/Counter-Terrorism-Fusion-Centre (dostęp: 11.03.2017) 
z terroryzmem. Pozostałe projekty realizowane przez CTF koncentrują się na takich kwestiach, jak wykorzystanie przez terrorystów Internetu i mediów społecznościowych, a także zagadnienia związane z porwaniami dla okupu ${ }^{19}$.

Omówione przedsięwzięcia sprawiają, że centrum CTF pełni rolę swoistego węzła łączącego różne źródła wywiadowcze w kwestii działalności grup terrorystycznych. Umożliwia to zarówno bieżącą reakcję na konkretne problemy pojawiające się $\mathrm{w}$ związku z działalnością zagranicznych bojowników terrorystycznych, jak i wyciąganie wniosków o charakterze ogólnym, służących wypracowaniu przez Interpol długookresowej strategii zwalczania terroryzmu.

Podsumowując, należy stwierdzić, że Interpol odgrywa ważną i pozytywną rolę $\mathrm{w}$ zwalczaniu problemu tzw. zagranicznych bojowników terrorystycznych. Wynika ona przede wszystkim z globalnego charakteru tej organizacji (do której należy obecnie 190 państw z całego świata). Stworzony przez Interpol system łączności i wymiany informacji, rozbudowane bazy danych oraz szerokie i zróżnicowane wsparcie udzielane państwom członkowskim bez wątpienia podnoszą skuteczność działań wymierzonych w przestępczość, co dotyczy również zwalczania terroryzmu. W przypadku wielu państw, nieobjętych współpracą policyjną w wymiarze regionalnym, jest to zresztą jedyna forma wielostronnej kooperacji w walce z przestępczością, stwarzająca tak duże możliwości. Warto również pamiętać, że Interpol w ramach wykonywania swoich zadań ściśle współpracuje z wieloma podmiotami, zarówno regionalnymi (tutaj szczególnie dynamicznie rozwija się współdziałanie z Europolem), jak też organizacjami należącymi do systemu ONZ. Od wielu lat Interpol kooperuje również z podmiotami prywatnymi, chociaż pod tym względem istnieją pewne ograniczenia, gdyż pełny dostęp do zasobów tej organizacji mogą mieć wyłącznie służby policyjne.

Obecnie priorytetem Interpolu w walce z problemem zagranicznych bojowników terrorystycznych jest takie udoskonalenie systemu wymiany informacji, aby dane pozwalające na podjęcie konkretnych działań były dostępne stosownym służbom w punktach granicznych, zwłaszcza w tych kluczowych rejonach, które znajdują się na głównych trasach przemieszczania się takich osób ${ }^{20}$. Dotyczy to zwłaszcza krajów Bliskiego Wschodu, w których zwiększenie świadomości sytuacyjnej miejscowych służb w tym zakresie wydaje się kluczowe, pod względem zarówno działań prewencyjnych, jak i zwalczania istniejących już zagrożeń.

Oceniając pozytywnie działalność Interpolu w walce z problemem zagranicznych bojowników terrorystycznych, nie należy jednak zapominać, że aktywność organizacji międzynarodowych $\mathrm{w}$ tym zakresie nie zastąpi wysiłków podejmowanych przez same państwa, na których to właśnie działaniach powinien spoczywać główny ciężar rozwiązania tego problemu. Trzeba bowiem pamiętać, że Interpol nie dysponuje żadnymi siłami wykonawczymi, co jest wynikiem

\footnotetext{
19 Ibidem.

20 Ibidem.
} 
braku uprawnień do wykonywania jakichkolwiek czynności procesowych. Jego rola jest inna; w wymiarze praktycznym polega ona bowiem przede wszystkim na organizowaniu systemu międzynarodowych poszukiwań policyjnych oraz na realizacji procesów wywiadu kryminalnego (gromadzenie, przetwarzanie, analiza i wymiana informacji kryminalnych) ${ }^{21}$. Z tego też względu to na poszczególnych państwach spoczywa obowiązek stworzenia skutecznych regulacji prawnych penalizujących udział ich obywateli w działaniach zbrojnych w szeregach ugrupowań terrorystycznych, co niestety w niektórych krajach nie zostało dostatecznie szybko dostrzeżone. Dopiero realizacja tego postulatu sprawi, że można będzie mówić o większych gwarancjach skuteczności międzynarodowej współpracy policyjnej. W walce z przestępczością ujęcie osoby podejrzanej jest bowiem tylko jednym z etapów w (niejednokrotnie długiej) procedurze, której efektem powinno być ustalenie prawdy materialnej i wydanie sprawiedliwego wyroku kończącego postępowanie karne.

\section{Bibliografia}

Izak K., Imigranci a prawo, dokumenty i bezpieczeństwo narodowe, „Człowiek i Dokumenty” 2016, styczeń-marzec.

Kołdys B., BMWP KGP - Krajowe Biuro Interpolu, „Kwartalnik Policyjny” 2014, $\mathrm{nr} 4$.

Kołecki H., Działalność Interpolu w zakresie zwalczania terroryzmu międzynarodowego, [w:] Terroryzm. Aspekty prawno-międzynarodowe, kryminalistyczne i policyjne, red. K. Sławik, Materiały Sympozjum zorganizowanego przez Wydział Prawa Uniwersytetu Szczecińskiego, Szczecin, 29-30.11.1991, Poznań 1993.

Rękawek K., Zagraniczni bojownicy w Syrii i Iraku: skala problemu i zagrożenie dla Europy, „Biuletyn PISM" 2014, nr 110.

Safjański T., Charakterystyka wybranych metod i form realizacji przez Interpol zadań zwiazanych z przeciwdziałaniem przestępczości międzynarodowej, „Kwartalnik Policyjny” 2016, nr 2.

Safjański T., Prawne aspekty wykorzystania wsparcia Interpolu w poszukiwaniu osób podejrzanych w świetle art.605a k.p.k., „Prokuratura i Prawo” 2016, nr 10.

Zgryziewicz R., Strategia komunikacyjna Daesh zagrożeniem dla wspótczesnej Europy, „e-Politikon" 2016, nr XX.

\section{Źródła internetowe}

https://www.interpol.int/content/download/29749/390579/version/3/file/Information\%20Sheet-Foreign\%20Fighter.pdf

https://www.interpol.int/Crime-areas/Terrorism/Counter-Terrorism-Fusion-Centre

https://www.interpol.int/INTERPOL-expertise/Border-management/SLTD-Database

https://www.interpol.int/INTERPOL-expertise/Data-exchange/I-24-7

https://www.interpol.int/INTERPOL-expertise/Notices

21 T. Safjański, Charakterystyka wybranych metod i form realizacji przez Interpol zadań związanych z przeciwdziałaniem przestępczości międzynarodowej, „Kwartalnik Policyjny” 2016, nr 2, s. 86.

Studia nad Autorytaryzmem i Totalitaryzmem 40, nr 1, 2018

(C) for this edition by CNS 
https://www.interpol.int/INTERPOL-expertise/Notices/Special-Notices

http://www.interpol.int/Public/FusionTaskForce/objectives.asp

http://www.policechiefmagazine.org/interpol-i-checkit-proactive-policing/

\title{
INTERPOL IN THE FACE OF THE PROBLEM OF SO-CALLED FOREIGN TERRORIST FIGHTERS
}

\section{Summary}

The challenges for present security include the problem of so-called foreign terrorist fighters. Threats concerned this issue are different, and they are a subject of interest of both countries and international organizations, including Interpol. The International Criminal Police Organization, being a worldwide entity, has broad possibilities of support of its member countries in fight against the above mentioned problem. This support concerns mainly help regarding an access to information, as well as coordination of actions being undertaken by law enforcement agencies.

Keywords: Interpol, terrorism, foreign terrorist fighters

\author{
Adrian Szumski \\ adrian.szumski@uni.wroc.pl
}

